\title{
Front Matter: Volume 11775
}

, "Front Matter: Volume 11775," Proc. SPIE 11775, Integrated Optics: Design, Devices, Systems and Applications VI, 1177501 (11 May 2021); doi: 10.1117/12.2599087

SPIE. Event: SPIE Optics + Optoelectronics, 2021, Online Only 


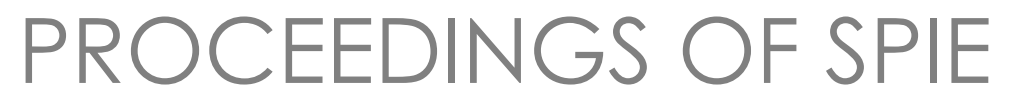

\title{
Integrated Optics: Design, Devices, Systems and Applications VI
}

\author{
Pavel Cheben \\ Jirî́ Čtyroký \\ Iñigo Molina-Fernández \\ Editors
}

19-23 April 2021

Online Only, Czech Republic

Sponsored by

SPIE

Cooperating Organisations

ELI Beamlines (Czech Republic)

Laserlab Europe

European Optical Society

HiLASE Centre (Czech Republic)

Published by

SPIE 
The papers in this volume were part of the technical conference cited on the cover and title page. Papers were selected and subject to review by the editors and conference program committee. Some conference presentations may not be available for publication. Additional papers and presentation recordings may be available online in the SPIE Digital Library at SPIEDigitalLibrary.org.

The papers reflect the work and thoughts of the authors and are published herein as submitted. The publisher is not responsible for the validity of the information or for any outcomes resulting from reliance thereon.

Please use the following format to cite material from these proceedings:

Author(s), "Title of Paper," in Integrated Optics: Design, Devices, Systems and Applications VI, edited by Pavel Cheben, Jiř́ Čtyroký, Iñigo Molina-Fernández, Proc. of SPIE 11775, Seven-digit Article CID Number (DD/MM/YYYY); (DOI URL).

ISSN: 0277-786X

ISSN: 1996-756X (electronic)

ISBN: 9781510643840

ISBN: 9781510643857 (electronic)

Published by

SPIE

P.O. Box 10, Bellingham, Washington 98227-0010 USA

Telephone +1 3606763290 (Pacific Time)

SPIE.org

Copyright @ 2021 Society of Photo-Optical Instrumentation Engineers (SPIE).

Copying of material in this book for internal or personal use, or for the internal or personal use of specific clients, beyond the fair use provisions granted by the U.S. Copyright Law is authorized by SPIE subject to payment of fees. To obtain permission to use and share articles in this volume, visit Copyright Clearance Center at copyright.com. Other copying for republication, resale, advertising or promotion, or any form of systematic or multiple reproduction of any material in this book is prohibited except with permission in writing from the publisher.

Printed in the United States of America by Curran Associates, Inc., under license from SPIE.

Publication of record for individual papers is online in the SPIE Digital Library.

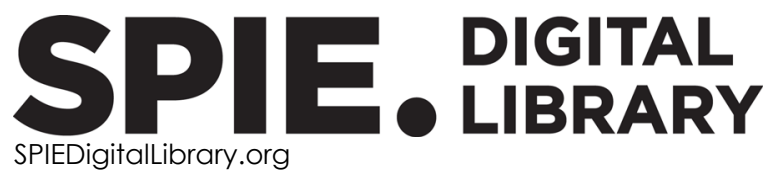

Paper Numbering: A unique citation identifier (CID) number is assigned to each article in the Proceedings of SPIE at the time of publication. Utilization of CIDs allows articles to be fully citable as soon as they are published online, and connects the same identifier to all online and print versions of the publication. SPIE uses a seven-digit CID article numbering system structured as follows:

- The first five digits correspond to the SPIE volume number.

- The last two digits indicate publication order within the volume using a Base 36 numbering system employing both numerals and letters. These two-number sets start with 00, 01, 02, 03, 04, 05, 06, 07, 08, 09, 0A, OB ... 0Z, followed by 10-1Z, 20-2Z, etc. The CID Number appears on each page of the manuscript. 


\title{
Contents
}

\author{
KEYNOTE SESSION
}

$1177504 \quad$ Microcombs for ultrahigh bandwidth optical data transmission and neural networks (Keynote Paper) [11775-1]

\section{DEVICES AND SYSTEMS}

11775 OE Silicon photonic devices for wavelength/mode-division-multiplexing (Invited Paper) [11775-10]

11775 OG High-speed germanium p-i-n avalanche photodetectors on silicon (Invited Paper) [11775-12]

11775 OK Three-dimensional tunable true time delay line [1 1775-16]

$11775 \mathrm{OL} \quad$ Analysis of BTO-on-Si-waveguides for energy-efficient electro-optical modulators [11775-17]

\section{LASERS AND ACTIVE DEVICES}

11775 OM Quantum dot multi-wavelength for high capacity 5G fiber-wireless integrated mobile fronthaul and access links (Invited Paper) [11775-18]

11775 OP Monolithic and hybrid integration of InAs/GaAs quantum dot microdisk lasers on silicon [11775-21]

$117750 Q \quad$ Two-dimensional distributed feedback lasing with colloidal quantum dots in photonic quasicrystals [11775-23]

11775 OR Passive Q-switched generation of all-fiber heavily erbium-doped laser [11775-24]

11775 OS Versatile linearly polarized photon generation from a quantum emitter in metasurface-decorated waveguides [11775-25]

11775 OT Acousto-optic tunable filter for tuning a copper vapor laser [11775-26] 
11775 OV Discussion on the principle of coupling and optimization of fiber-to-resonator coupling [11775-28]

11775 OW Design of an analyzer based on a quantum cascade laser for substance identification by infrared reflected radiation [1 1775-29]

\section{POSTER SESSION}

11775 OX Saturable absorber for ring fiber lasers on the base of coupler coated by CNTs [11775-22]

11775 OY Micro-Raman to detect stress phenomena in Si-chips bonded onto Cu substrates [11775-30]

1177511 Compressive single pixel phosphorescence lifetime and intensity simultaneous imaging: a pilot study using oxygen sensitive biomarkers [11775-33]

1177512 FTIR spectroscopy based on a multipass gas cell and TE cooled HgCdTe sensors for environmental monitoring and defense applications [11775-34]

1177513 Determination of a statistical lack of volume matter by resonance principle: experiential approach and modeling [11775-35]

1177514 Analysis of giant waveguide tapers with funnel geometry: multi-mode interference regime to single mode [11775-36]

$1177515 \quad$ Efficient visible light communication drivers using illumination LEDs in industrial environments [11775-37]

$1177519 \quad$ An efficient mixed-signal dielectric-partitioning model of liquid crystals based shielded coplanar waveguide for electronically reconfigurable delay lines design [11775-42]

11775 1B Energy backflow in tightly focused cylindrical vector beam with fractional order [11775-44] 